\title{
CRACOW IN THE LIFE AND WORK OF EDVARD JELÍNEK
}

\author{
Petr Kaleta
}

(1) http://orcid.org/0000-0002-3292-9901

Pedagogical University of Cracow

\section{ABSTRACT \\ CRACOW IN THE LIFE AND WORK OF EDVARD JELÍNEK}

This study describes and analyzes Czech polonophile Edvard Jelínek's relationship with the city of Cracow as reflected in his books and articles. Jelínek had extensive contacts in Cracow with leading representatives of Polish literature and culture (such as Władysław Anczyc, Adam Asnyk, Michał Bałucki and Adam Honory Kirkor), through whom he gained access to important city institutions and landmarks. After Warsaw, Cracow was Jelínek's favorite Polish city, and he mentioned it in many of his writings. Jelínek also published several articles in the local press and, as a capable organizer of Czech-Polish cultural and scientific events, he contributed greatly to an 1884 pilgrimage to Cracow, under the auspices of Kolín's Sokol, that was undertaken by more than 1,300 Czechs.

Keywords: Edvard Jelínek, Cracow, publications, local landmarks, famous individuals.

\section{INTRODUCTION}

In the world of Czech polonophilia and Czech-Polish relations, one name stands above the rest, one person who, during his relatively short life, contributed most visibly to fostering mutual understanding between Czechs and Poles among both nations. This person was the writer, journalist, translator and promoter of intra-Slavic relations Edvard Jelínek ${ }^{1}$ (1855-1897). Jelínek's role in Czech-Polish relations is perhaps best captured by the words of his friend and collaborator in intra-Slavic matters Adolf Černý, who wrote in a comprehensive obituary in 1897 that "Edvard Jelínek has become so closely associated with Poland that one cannot imagine a closer and

\footnotetext{
1 In his Polish writings, Edvard Jelínek signed his name as "Edward Jelinek," but in this article we retain its original Czech form, i.e., "Edvard Jelínek" or "E. Jelínek."
} 
more inseparable union. No other Czech has been as prominent a representative and communicator of the efforts and life of any Slavic nation as Jelínek was a communicator and patron of the Polish nation in Czech literature."2 Jelínek enjoyed exploring and describing in his works all areas of divided Poland-large and small cities, nature (especially the Tatras), and the rural countryside. He focused much attention on the main center of Polish culture and the country's largest city-i.e., Warsaw and its famous salons - but he did not forget Cracow, which differed significantly from the Polish capital. Edvard Jelínek's oeuvre is vast and extensive even if we look only at his works published at home, not to mention those published in Polish or other Slavic publications. Jelínek's writings covered many subjects, primarily in the area of Czech-Polish relations in the $19^{\text {th }}$ century. His life and work have been described in several extensive publications. ${ }^{3}$ In this text, we will focus on Jelínek's contacts with Cracow and its leading inhabitants and on his writings related to the city. At the same time, very little is known about his organizatorial activities in the area of CzechPolish cooperation, which is why the text focuses in particular on the large Czech pilgrimage to Cracow organized in 1884. For this reason, the study's main sources of information are newspaper and magazine articles.

\section{EDVARD JELÍNEK}

Edvard Jelínek was born on 6 June 1855 into the family of the lithographer Josef Jelínek in Prague, where he also attended the local reálné gymnázium [grammar school]. In 1872, he began working at Prague's town hall, where he spent the final years of his life as an adjunct in the city's statistics office. During all this time, however, he devoted all his free time to writing and traveling in order to fulfill his resolution for Slavs to "get to know one another." He was interested in the latest news from all areas of Slavic life, and like many Czech intellectuals of his time his first exposure to other Slavic nations was to the culture, literature, and language of Poland and Russia. According to A. Černý, Jelínek learned the basics of the Polish language from teacher Józefa Nowicka when she spent several months in Prague in $1872 .{ }^{4} \mathrm{He}$ spent the subsequent months intensively studying Polish on his own - an effort that among other things resulted in his first translation from Polish, specifically Paulina Wilkońska's play Svatý obrázek [The Holy Card], which was published in 1875 in volume 91 of the Divadelni ochotnik series. Late in life, writing with his typical sense

2 A. Černý, Za Edvardem Jelínkem. Zvláštni otisk ze Světozora čís. 1552-1557, Praha 1897, p. 6. Original: "Edvard Jelínek u nás tak srostl s Polskem, že si nelze mysliti spojení užšího a nerozlučitelnějšího. Není u nás druhého tak vysloveného zástupce a tlumočníka snah a života kteréhokoliv národa slovanského, jako byl Jelínek v naší literatuře tlumočníkem a patronem národa polského."

3 In particular the work of Adolf Černý, Viktor Juřina, and Barbara Jaroszewicz-Kleindienst; see "Bibliography."

4 A. Č. [A. Č erný], “Z deníku Edvarda Jelínka,” Máj 3, 1905, no. 9, p. 140. After Nowicka’s departure, Jelínek continued to correspond with her until the year 1890. 
of modesty, Jelínek recalled what had been of the greatest help during his translational debut: "There is no doubt that the main credit goes to Podstránský's portable dictionary, and perhaps even more so to the simple style and not too philosophical plot of this simple and innocent Polish drama." Jelínek's first writings on the subject of Poland and Polish culture date from 1873, when he was just eighteen years old: a brief text describing interesting details from the life of Chopin published in the Czech magazine Dalibor ${ }^{6}$ and a short story about an encounter with an elderly Pole containing clear elements of Polish patriotism and the country's tragic history in the $19^{\text {th }}$ century, published in the magazine Obrazy života. ${ }^{7}$ Also that year, he published his first article in a Polish periodical, a list of Polish works translated into Czech. ${ }^{8}$

In the mid-1870s, Jelínek diligently continued to study Polish and Russian while also delving further into Polish culture and literature. By then, he had already established his first contacts with various figures from Polish and Russian cultural life, but he realized that any deeper understanding would require traveling in person to visit the centers of culture that interested him most. And so, in 1876, he embarked on his first Slavic journey (as he called it), during which he visited Cracow, Warsaw, Vilna, and St. Petersburg. ${ }^{9}$ Especially in Warsaw, Jelínek made important contacts for his later activities; the visit paved the way for further trips to various other parts of Poland, where he often sought inspiration for his literary works. He was extremely captivated by Warsaw, where he found many friends and came to more closely understand the causes and consequences of Russo-Polish tensions. But he also made longterm contacts in many other important cities. His Polish improved significantly with his further travels throughout Poland and as he published more and more articles at home and in Polish periodicals. According to his close friend Adolf Černý, "He was all the more capable of this task because of his perfect mastery of the Polish language and because his constant studies allowed him to delve into its most subtle folds and shadows - in short, because he wrote like a native-born Pole." 10

It is not our aim to describe and analyze Jelínek's writings, but we should nevertheless point out several of his important works. By the early 1880s, Jelínek had gained renown in Czech and foreign circles as the editor of the Slovanskýsbornik [Slavonic Symposium], which in its time (six volumes were published in 1881-1887) was one of the most respected journals dedicated to Slavic themes. Besides contributing to the Slavonic Symposium, he wrote articles, columns, news reports, bibliographies, short stories, dramas, and more for numerous other periodicals in Bohemia and

5 A. Černý, Vzpomínky Edvarda Jelínka, Praha 1904, p. 30 [chapter: "První honorár"]. Original: "Není pochybnosti, že hlavní o to měly zásluhu Podstránského příruční slovník a snad ještě více prostičký sloh i pranic filosoficky hluboký děj této arcinevinné dramatické hříčky polské."

6 E. J. [E. Jelínek], “Ze života Bedřicha Chopina,” Dalibor 1, 5.12.1873, no. 49, p. 403.

7 E. J. [E. Jelín ek], “Z ujazlovských sadů,” Obrazy života 3, 10.8.1873, no. 21, pp. 330-331.

8 E. Jelínek, “Spis dzieł polskich na język czeski przełożonych,” Tygodnik Wielkopolski 3, 22.3.1873, no. 12 , pp. 142-143; 24.8.1873, no. 34, pp. 406-407.

9 Cf. A. Č erný, Vzpomínky Edvarda Jelínka, pp. 98-112 [chapter: "Varšava. První cesta"].

10 A. Černý, “Za Edvardem Jelínkem,” Světozor 31, 26.3.1897, no. 20, p. 237. Original: "K úkolu tomu byl tím schopnějším, že ovládal dokonale jazyk polský, že jej neustálým studiem pronikl do nejjemnějších záhybů a odstínů, zkrátka, že jím psal jako rozený Polák.” 
abroad (primarily Polish magazines and newspapers). Some of his articles and essays also appeared (either concurrently or at a later date) as standalone publications. His independently published books and treatises on Polish or Slavic affairs include Polské paní a dívky [Polish Ladies and Maidens] (Prague 1884), Črty kozácké [Cossack Sketches] (Prague 1885), Črty litevské [Lithuanian Sketches] (Prague 1886), Pro shodu česko-polskou. Několik úvah věcných i historických [In Favor of a Czecho-Polish Accord: Several Objective and Historical Considerations] (Prague 1887), Dámy staršich salonưv polských [The Ladies of the Older Polish Salons] (Prague 1888), Slovanské návštěvy. Paměti a vzpomínky [Slavonic Visits: Memories and Remembrances] (Prague 1889), Črty varšavské [Warsaw Sketches] (Prague 1890), Věci polské [Polish Affairs] (Prague 1893), and Zapomenutý kout slovanský. Několik prvních pohledi̊ do kašubského Pomoř́ [A Forgotten Slavonic Land. Several Early Views of Kashubian Pomerelia] (Prague 1894). ${ }^{11}$ In addition, he also edited the fourth edition of Špachta's Mluvnice polská [Polish Grammar] (Prague 1882), to which he added a new reader and dictionary. Many of his writings were also published in other Slavic languages, especially Polish.

Edvard Jelínek never married, and spent his entire life sharing a two-room flat with his brother Viktor on the second floor of building number 31 on one corner of Haštal Square in Prague's Old Town. ${ }^{12} \mathrm{He}$ was well known among long-time residents as someone who (when he wasn't on one of his Slavic journeys) had a daily habit of leaving the house at six o'clock for his regular walk along Na Př́kopě Street. Adolf Černý, who met Jelínek in 1884 and who often visited him as a friend in his home, offered a detailed description of Jelínek's study, including his writing table, library of Slavic litereature, and many interesting artifacts that he had brought home from his travels. ${ }^{13}$ Jelínek himself wrote in his memoirs that he had suffered from poor health since childhood. His involvement in the 1891 Jubilee Exposition required significant effort on his part, and his health quickly declined afterwards. He died on March 15, 1897 and was buried three days later in a temporary grave at Vyšehrad. In the fall of that year, his remains were transferred to a final resting place next to the author Božena Němcová. ${ }^{14}$

${ }_{11}$ An incomplete bibliography of Edvard Jelínek's writings can be found in: F. Krček, Edward Jelinek, [Lwów 1897, offprint from the periodical "Przewodnik Naukowy i Literacki"]; V. Juřin a, Edvard Jelinek - osobnost a dilo [Praha 1951, dissertation, Jan Palach Library, Faculty of Arts, Charles University], pp. 126-139; B. Jaroszewicz-Kleindienst, W kręgu polonofilskiej działalności Edwarda Jelínka, Wrocław-Warszawa-Kraków 1968, pp. 161-174.

12 Cf. V. Kredba, “Ze vzpomínek na Edvarda Jelínka," Slovanský Přehled 27, 1935, p. 405.

13 A. Č erný, Za Edvardem Jelinkem. Zvláštni otisk ze Světozora čis. 1552-1557, pp. 23-27.

14 Cf. A. Černý, "Edvarda Jelínka život a práce," Slovanský přehled 7, 1905, p. 99. 


\section{THE SOKOL PILGRIMAGE TO CRACOW}

Theater was an integral part of Czech culture, and as a model patriot Edvard Jelínek was a great lover of Czech theater. He wrote his own plays, and translated other authors' works into Czech (especially from Polish) and from Czech into Polish and Russian. For these reasons, he closely followed the process of founding of the National Theatre in Prague as a symbol of the Czech people's growing sense of national consciousness. He wrote frequently about Czech theater, especially in the Polish press, including a significant number of articles about the National Theatre. At the same time, he worked to get Czech dramas shown in Poland and Polish dramas shown back home. After the National Theatre was damaged by fire in 1881, Jelínek immediately began to inform his Polish friends and Polish newspapers and magazines about the event. The response from all of Poland's centers of culture was enormous. Contributions came from the cities of Lvov and Cracow, and public collections were organized in Lvov, Cracow, Poznań, and other cities. In addition, Lvov and Cracow hosted several benefit theater performances to raise funds for the National Theater. ${ }^{15}$ To a significant extent, this response on the part of Poland's cultural circles was thanks to Jelínek, who constantly worked to promote Czech cultural and literary events in Poland and Polish events in the Czech lands. He was also an excellent organizer, and a full six months before the National Theatre's official reopening in 1883 he began inviting representatives from Warsaw, Cracow, Poznań, and Lvov to attend, and carefully planned their stay in Prague. ${ }^{16}$ The success of this visit brought Jelínek to the idea of organizing an even greater undertaking - a trip by a group of Czechs to Poland, envisioned for the following year, 1884. The destination of this pilgrimage would be the ancient city of Cracow.

Jelínek's idea was subsequently taken up by the Sokol group in the town of Kolín, which succeeded in organizing a grand journey. The undertaking was covered in detail by the press: Starting in mid-May 1884, the Národni listy in particular began publishing detailed reports on the planned trip and the constantly growing number of participants. The group left for Cracow and Wieliczka on 15 August on special trains that departed Prague at 9 a.m. and Kolín at 11 a.m. Each participant received a guide to Cracow and Wieliczka and a badge commemorating the occasion. The main participants were the members of various Sokol units in their folk costumes, but the trip was open to anyone. ${ }^{17}$ There was such great interest that by June (two months before departure) the planned capacity had been filled and the organizers had to cancel a planned overnight stay in Přerov. ${ }^{18}$ On the day of departure, Kolín's Sokol club published a special edition of its newspaper, the Výletni listy, with a detailed

15 J. [E. Jelínek], "Bratři Poláci a naše Národní divadlo," Divadelní listy 2, 10.9.1881, no. 29, pp. $255-256$.

16 A.Černý,VzpomínkyEdvarda Jelínka,p. 55 [chapter: “Divadelní táčky. (Veselé i melancholické)”].

Cf. V. Juřin a, Edvard Jelínek - osobnost a dílo, pp. 57-58.

17 "Výlet do Krakova," Př́loha Národnich listů 24, 16.5.1884, no. 136, p. 5.

18 "K výletu do Krakova a do Věličky," Národní listy. Odpolední vydání 24, 13.6.1884, no. 163, p. 2. 
description of the journey from Kolín to Cracow, an article on Polish history, a piece on the history of the Czech Sokol movement, and practical instructions for participants. ${ }^{19}$ A day before the group's departure for Cracow, František L. Hovorka published a newspaper article titled Některé mravy a zvyky polské [Some Polish Customs and Traditions $],{ }^{20}$ in which he offered a positive and highly accurate description of the Polish people and also discussed Czech-Polish relations. In a self-critical assessment, he recalled the past actions of some Galician Czechs, which had had a negative impact on Czech-Polish relations: "Up to a certain time, the Poles were quite skeptical of us Czechs. They deemed that we did not wish them well, and then more than a few of our countrymen in Galicia besmirched our nation's good name. This was the consequence of the earlier political system ... It is no wonder that the Poles harbored a lack of faith in such 'Czechs,' which they then projected onto our nation as a whole." 21 The article ended on an optimistic note by pointing out that the two nations had come to know each other better in recent years and that the period of mutual mistrust had been overcome. The author also emphasized that the trip to Cracow could be a suitable way of further strengthening the relationship between Czechs and Poles.

Famous persons who participated in this grand event included member of the Bohemian Diet and Imperial Council Čeněk Hevera of Kolín, journalist and member of the Imperial Council Emanuel Tonner, Polish Slavist and author Bronisław Grabowski, author František Herites, and (besides Edvard Jelínek) two additional polonophiles: poet and Polish-Czech translator František Kvapil and Polish-Czech translator Arnošt Schwab-Polabský. One interesting fact that shows the national character of the journey is that the State Railway Company issued the special ticket from Prague to Cracow exclusively in Czech, the train personnel was entirely Czech, and the station announcements at all planned stops along the way were in Czech only. ${ }^{22} \mathrm{On}$ the scheduled date, 15 August 1884, more than 1,300 Czechs arrived in Cracow on three trains. Altough the dominant group was the Sokol delegation, there were representatives from a wide variety of professions and social groups. Jelínek did not hold back his excitement at how well the self-aware Czech nation had succeeded in demonstrating its unity. He described the participants of the Cracow expedition as follows: "It was the will and desire of all who constitute the nation: the Czech farmer, craftsman, merchant, factory owner, industrialist, student, teachers, authors, scholars, and representatives of the people on the regional and imperial councils. They were wealthy and poor, old and young, ladies and girls! It was the nation, and its expressions were

\footnotetext{
19 "K výletu do Krakova," Př́loha Národních listů 24, 11.8.1884, no. 222, p. 3.

20 F. L. Hovorka, "Některé mravy a zvyky polské," Národni listy. Odpolední vydáni 24, 14.8.1884, no. 225 , pp. $1-2$.

${ }_{21}$ Ibid., p. 2. Original: "K nám Čechům chovali se Poláci do jisté doby dosti nedůvěřivě. Soudili, že jim nepřejeme, a pak nejeden náš rodák zhanobil v Haliči poctivou pověst českého jména. Byl to následek dřívějšího politického systemu . . . Nic divného, že k takovým ‘Čechům’ chovali Poláci nedůvěru, již pak přenášeli na celý náš národ."

22 “Česká pout' do Krakova," Národní listy 24, 16.8.1884, no. 227, p. 2.
} 
not of a limited but of a universal, national character. ${ }^{23} \mathrm{He}$ was also delighted by the fact that the pilgrimage had fortified the sense of solidarity between Bohemians and Moravians, as could be seen among other places in Olomouc, which hosted a parade by the pilgrims, who were welcomed with great enthusiasm (as they were in other towns as well).

After their arrival in Cracow and their official welcome at the train station-where they were met, among others, by members of the Sokol organization from Lvov-the entire delegation headed for town hall. In the council chambers, imperial councilor Emanuel Tonner spoke in Polish on behalf of the Czech visitors and Mayor Ferdynand Weigl spoke on behalf of the city of Cracow. Over the next three days, a full program including many meetings with Polish friends awaited the pilgrims. Among other things, they visited the Kościuszko Mound, where the Kolín Sokol delegation laid a grandiose wreath. Czech authors had the chance to meet with leading Polish writers, scientists, and artists, and there were meetings of teachers, students, and other groups as well. Important places visited by the Czechs included Wawel Hill, the town of Wieliczka, and the Jagiellonian Library. The friendly atmosphere culminated in a festive celebration in the nearby village of Bielany, where the Czech delegation was treated to a feast by the town of Cracow. ${ }^{24}$ Jelínek saw the Kolín Sokol club's trip to Cracow - and especially its successful nature - as another positive shift in CzechPolish relations that was of great importance to the future of both nations.

The organizing of grand undertakings aimed at promoting Czech-Polish friendship was one of Jelínek's strong suits. During the 1891 Jubilee Exposition in Prague, he selflessly looked after Polish guests to the city and contributed significantly to the large number of Poles - around 5,000 - to visit the expo. ${ }^{25}$ Several of the Polish visitors took a side trip to Karlštejn, after which it was agreed that, in return, there would be another excursion of Czechs to Poland. This journey, which took place in August 1892, was organized by the Klub českých turistů [Czech Tourist Club] with support from Poland's Towarzystwo Tatrzańskie [Tatra Society]. The destination: Cracow, Wieliczka, and especially the Tatra Mountains. ${ }^{26}$ In the Tatras, the 36 participants in the Czech Tourist Club's first Slavic tour were looked after primarily by the painter, photographer, and great lover of the mountains professor Walery Eljasz-

23 E. Jelínek, “Česká pout’ do Krakova 15.-18. srpna 1884,” Slovanský sborník 3, 1884, no. 10, p. 530. Original: "Byla to vůle a tužba všech, kdož stanoví národ: českého rolníka, řemeslníka, obchodníka, továrníka, průmyslníka, studenta, učitelstva, spisovatelstva, učence i zástupce lidu na radách zemských i říšských. Byli možní i bědní, staří i mladí, paní i dívky! Byl národ a projevy jeho neměly ráz obmezený, nýbrž povšechný, národní."

24 Besides Národní listy, for information on the expedition to Cracow see also: E. Jelín ek, "Česká pout' do Krakova 15.-18. srpna 1884," pp. 530-537.

25 Cf. A. Černý, “Za Edvardem Jelínkem,” Světozor 31, 2.4.1897, no. 21, p. 247.

26 See the articles: "Výlet do Tater pořádá Klub českých turistů v měsíci srpnu," Časopis turistů 4, July 1892, no. 7, pp. 169-170; "Na Vysoké Tatry," Časopis turistů 4, August 1892, no. 8, pp. 203-216; “Po návratu z Tater,” Časopis turistů 4, September 1892, no. 9, pp. 235-236; L. M., "Dolina Kościeliská. Z upomínek na cestu do Tater," Časopis turistů 4, October 1892, no. 10, pp. 269-271, November 1892, no. 11, pp. 284-288; "Polské hlasy o nás," Časopis turistů 4, October 1892, no. 10, pp. 271-272; November 1892 , no. 11 , pp. 288-290. 
Radzikowski and his family, who also organized their daily program. Edvard Jelínek was unable to participate in person, but he at least managed to send the participants a telegram, which was read by Eljasz-Radzikowski. ${ }^{27}$

\section{CRACOW, ITS SIGHTS, AND ITS INSTITUTIONS}

Jelínek turned his attention to the city of Cracow in many articles and newspaper columns, although most of them were small mentions of minor elements in the city towards which he had some kind of personal relationship. Already at the start of his journalistic career, when his interest in Poland was just beginning, he wrote a column about the city in which, comparing Cracow to Warsaw, he described Cracow's atmosphere as follows: "If we compare the ancient seat of the Polish kings with sprawling Warsaw, we feel as if we have left behind a clamorous maelstrom and entered a silent study and prayer room." ${ }^{28} \mathrm{He}$ also noticed a kind of competitiveness between residents of the two cities, remarking for instance that Warsawers claimed that Cracow lacked a vibrant social life. Although Jelínek described the city's dominant landmarks such as Wawel Hill or the main square with the Cloth Hall, he saw Cracow mainly as a city of artists, scholars, and cultural institutions. Jelínek captured the differences between this ancient town and modern Warsaw of the $19^{\text {th }}$ century in an article about the latter in which he wrote that, all in all, Warsaw was a city of the era, adding that "if I were to compare Warsaw to Cracow, I would say that Cracow is a dignified matron that lives through the past. It likes to go to church, and engages in demonstrative displays of pomp only on especially festive or monumental occasions. Otherwise it quietly tinkers away and prays, and lives a God-fearing and hard-working life. But when the voice of old Sigismund resounds on Wawel Hill, this venerable matron dresses in a splendid robe of the old style, aglow with thick samite, sumptious brocade, and gilding." ${ }^{29}$ Clearly, Jelínek quickly understood the importance of the patriotic support of Cracow's Polish nobility (thanks to whom the city boasted three public picture galleries in the early 1880s). Important local supporters of the arts

27 L. M., "Dolina Kościeliská. Z upomínek na cestu do Tater," Časopis turistů 4, November 1892, no. 11, p. 287; "Polské hlasy o nás," Časopis turistů 4, November 1892, no. 11, p. 288.

28 E. Jelín ek, "Krakov," Národní listy 20, 4.9.1880, no. 213, p. 1. Original: “A porovnáme-li starožitnou stolici králův polských s bujnou Varšavou, zdá se nám, jakobychom přišli z hlučného víru do tiché pracovny a modlitebny.”

29 E. Pravda [E. Jelín ek], "Varšava a její společnost. Dojmy,” Slovanský sborník 6, 1887, no. 8, p. 358. Original: "Kdybych měl přirovnati Varšavu ke Krakovu, řekl bych, že Krakov je ctihodnou matrónou, kterážto žije minulostí. Chodí ráda do kostela a okázalost’ svou projevuje demonstrativně jen v okamžicích zvláště slavných nebo památných. Jinak tiše po domácku kutí a modlí se, trávíc život bohabojný a pracovitý. Když však zazní na Vavelu hlas starého Sigmunda, odívá se tato ctihodná matrona nádherným rouchem starého slohu: stkví se těžký aksamit, drahý brokát, práce zlatnická." 
whom Jelínek mentioned in his writings included members of the landed gentry such as the Siemiradzki family, as well the aristocratic Czartoryski and Potocki families..$^{30}$

Jelínek also paid close attention to social life in $19^{\text {th }}$-century Poland and enjoyed attending the country's famous salons, although it is clear that social and cultural life in Cracow during Jelínek's time could not compare to that in Warsaw. As a fan of theater, he emphasized that Cracow lagged behind Warsaw in theater culture, describing the city's winter theater as small and its summer theater as a provisional shack that was not a proper fit for this ancient city. ${ }^{31} \mathrm{He}$ observed the world of the Polish aristocracy and upper classes, ${ }^{32}$ but also paid attention to the poorest members of society. He must surely have been taken by the life of Cracow's poor, for in an 1879 article on begging and poverty he cited an 1861 article by Walery Wielogłowski claiming that begging had at that time become a true craft in just two cities - in Rome, the world capital of Catholicism, and in Cracow, the capital of Slavic Catholicism. Jelínek also cites Wielogłowski as saying that just as Rome draws idlers from all over Italy, so too is Cracow the center for similar people from Poland, Germany, Bohemia, and Silesia. Nevertheless, Jelínek points out that by the late 1870 s this description was no longer applicable, and as one person responsible for this change he cited the well-known philanthropist and organizer of charitable activities Zofie Potocka, whom he called the mother of Cracow's citizens. The city's poverty, he wrote, had moved elsewhere, for instance to Vilna. ${ }^{33}$

Edvard Jelínek took close notice of what made each city in Poland unique, with a focus primarily on places associated with national history and culture. He admired the Poles for the widespread presence of patriotic elements, and wrote about them in his articles and books. The place in Cracow that had the greatest impact on him was the Kościuszko Mound dedicated to one of the greatest heroes in Polish history. As a sacred place for the Polish nation, the hill made an immense impression on Jelínek during his first visit, as evidenced by an article he wrote in $1880 .{ }^{34}$ Working together with the French-born Polish author and photographer Juliusz (Jules) Mien, he first visited Wawel Cathedral, where the relatively modest sarcophagus of the citizen-general lying next to the ostentatious sarcophagi of the Polish kings made a lasting impression. The writer Władysław Anczyc then accompanied him to Kościuszko Mound. In later articles, Jelínek continued to remind Czech readers of the widespread Polish adherence to the ancient Slavic tradition of building mounds, of which the most beautiful and memorable was, in his view, Kościuszko Mound 188.

30 E. Jelínek, "Vlastenecká účinnost šlechty polské,” Slovanský sborník 4, 1885, no. 4, pp. 186-

31 E. Jelínek, “Obrazy z nynější Polsky. XII. Divadelní rozhled,” Národni listy 20, 24.8.1880, no. 203 , p. 1 .

32 Cf. E. Jelínek, "Bohatství a boháči v zemích slovanských. III.," Národní listy 20, 29.1.1881, no. 24 , p. 1 .

33 E. Jelínek, "Bída a milosrdenství v zemích slovanských. II.," Národní listy 19, 16.7.1879, no. 168 , p. 1.

34 E. Jelínek, “Obrazy z nynější Polsky. XIII. Kościuszko v hrobě a na kopci,” Národní listy 20, 16.9.1880, no. 223 , p. 1 . 
built in $1820-1823$ by citizens from the various parts of divided Poland.$^{35}$ It is thus no surprise that Jelínek visited the Cracow mound on each of his visits to town, usually setting out in the early morning hours with the rising of the sun. ${ }^{36}$ For similar reasons, the mound was on the itinerary of the Czech Sokol expedition in 1884. The culture of mound-building was very close to the heart of the patriotic Jelínek, and he regretted that nothing similar had ever been built in Bohemia. As he wrote in one of his articles: "On Poland's mounds I more than once asked myself why the idea of building giant mounds had not emerged back home. After all, we possess a sufficient number of suitable places, outstanding heroes, and equally memorable events in the life of our nation." ${ }^{37}$

Of Cracow's museums, Jelínek's interest focused in particular on the Muzeum Techniczno-Przemysłowe [Museum of Science and Industry], founded as a private institution in 1868 (like Náprstek's Czech Museum of Industry in Prague in 1862). Jelínek's guide was the museum's founder Adrian Baraniecki, who by then had managed to amass around 30,000 items. He was especially taken by the collection of richly decorated folk costumes from various regions of Poland and Ukraine and from the south Slavic nations. But the museum was more than a collection institution; it also worked together with selected girls' and boys' schools. On his tour, Jelínek was most captivated by the girls' fine art studies program. In particular, he was enchanted by the oil paintings made by a group of sixteen-year-old Polish girls under the guidance of the outstanding realist painter Hipolit Lipiński, who taught there. Other important elements of the museum's activities were its publishing activities and its public lectures featuring many leading personalities from Polish scientific and cultural life. Jelínek also tried to encourage his Czech readers to provide the museum with interesting items that might promote Czech culture. ${ }^{38}$ Unfortunately, after the Second World War the Museum of Science and Industry was nationalized and its collections were split up among other institutions. ${ }^{39}$

Edvard Jelínek was a bibliophile and an enthusiastic researcher who spent much of his free time in libraries and at scientific institutions. While working on the first volume of the Slavonic Symposium, he began to compile a bibliography of works from the Slavic regions that had been published in the Czech lands. With publication of the Slavonic Symposium, this project continued to grow, and Jelínek eventually

35 Cf. E. Jelínek, "Kościuszkova mohyla," Velký slovanský kalendár̆ na obyčejný rok 1889 18, 1888, pp. 101-102.

36 E. Jelínek, "Kościuszkova mohyla a kopec Unie lubelské," Slovanský sborník 3, 1884, no. 1, p. 47.

37 Ibid., p. 49. Original: "I rozjímal jsem na polských mohylách nejednou o tom, proč také u nás nevznikla myšlenka sypání mohutných mohyl. Vždyt’ máme k tomu dosti míst výhodných, bohatýrů znamenitých a událostí v národním životě stejně památných."

38 E. Jelínek, “'Muzeum techniczno-przemysłowe' v Krakově,” Národní listy 20, 7.9.1880, no. 215 , p. 1 .

39 The museum's name was changed twice over the course of the $20^{\text {th }}$ century, and the post-war era brought its eventual end. In 1950 it was made part of the National Museum in Cracow, and in 1951 the museum, its library, and a part of its collections were acquired by the Akademia Sztuk Pięknych im. Jana Matejki [Jan Matejko Academy of Fine Arts], thus completing the museum's liquidation. 
provided his carefully compiled bibliography to the relevant institutions, many of which published it as well (for instance, the Russian section was published by the Imperial Public Library in St. Petersburg, and the south Slavic section by the Serbian Scholarly Society in Belgrade). ${ }^{40}$ Due to his overwhelming interest in all things Polish, the Polish section was by far the largest. Over time, Jelínek expanded his contacts with the country's most important scientific institution, the Akademia Umiejętności w Krakowie [Academy of Learning], which had grown immensely since its founding in $1872 .{ }^{41}$ Each of the academy's three sections published its own magazine known as the Rozprawy, and it was the Rozprawy i Sprawozdania z Posiedzen Wydziatu Filologicznego that published Jelínek's ever-growing bibliography of Polish works published in the Czech lands. ${ }^{42} \mathrm{~A}$ part of this bibliography from the Rozprawy was later published as a separate volume. Edvard Jelínek remained in close contact with the members of the institution for the rest of his life and later, in 1894, published an article in Bohemia on the academy's origins, character, structure, and activities, based on information from its secretary-general Stanisław Smolka. ${ }^{43}$ Czech readers may have appreciated the information, mentioned in a footnote to his article, that past foreign members of the academy included the Czechs František Palacký, Josef Jireček, and Václav Štulc. Several other Czechs, including Václav Hanka and Boleslav Jablonský, had been members of an earlier scientific institution, the Towarzystwo Naukowe Krakowskie [Cracow Scientific Society]. ${ }^{44}$

Already in the early days of his interest in Poland, Jelínek endeavored to read all the most important Polish newspapers and magazines in all three parts of partitioned Poland, and so he soon understood the different conditions in each part. Although life was most difficult in Russian-occupied Poland-where the censors even banned magazines from printing the word "ojczyzna" [homeland], which had to be replaced with the word "kraj" [land, country] — magazine production in this part of the country far outpaced that in Austrian-occupied Galicia or the German-occupied Province of Posen. The political freedom in Galicia was even expressed through the differences between magazines. For instance, the rivalry between the region's two main centers

40 Cf. A. Černý, Vzpomínky Edvarda Jelínka, pp. 38-41 [chapter: "Kritik kavalír"].

41 The academy grew out of the Towarzystwo Naukowe Krakowskie, a scientific institution founded in 1815 .

42 E. Jelínek, "Biblijografija dzieł, rozpraw i artykułów czeskich dotyczących rzeczy polskich. (Do końca 1877 roku)," Rozprawy i Sprawozdania z Posiedzeń Wydziału Filologicznego Akademii Umiejętności 1880, t. VII, pp. 129-168; E. Jelín ek, "Biblijografija dzieł, rozpraw i artykułów czeskich dotyczących rzeczy polskich. Część druga 1878-1882," Rozprawy i Sprawozdania z Posiedzeń Wydziatu Filologicznego Akademii Umiejętności 1884, t. X, pp. 366-384; E. Jelínek, "Bibliografija przekładów z piśmiennictwa polskiego na język czeski (do końca 1882 roku)," Rozprawy i Sprawozdania z Posiedzeń Wydziału Filologicznego Akademii Umiejętności 1884, t. X, pp. 384-449; E. Jelínek, "Biblijografija dzieł, rozpraw i artykułów czeskich dotyczących rzeczy polskich. Część trzecia (1883-1886)," Rozprawy i Sprawozdania z Posiedzeń Wydziału Filologicznego Akademii Umiejętności 1889, t. XIII, pp. 159-181.

43 E. Jelínek, "Společnosti a ústavy polské, k nimž jest česká Akademie ve spojení vědeckém. I. Akademie věd v Krakově (Akademia Umiejętności w Krakowie.),"Věstník České akademie císaře Františka Josefa pro vědy, slovesnost a uměni 7, 1894, p. 371.

${ }^{44}$ Ibid., pp. 369-379. 
of culture and politics - Lvov and Cracow - was apparent on the pages of the city's two main periodicals. Cracow's Czas was more moderate in tone, while Lvov's Gazeta Narodowa reflected far-right viewpoints. Jelínek commented on $\mathrm{Czas}$, in which he later published himself, in an 1879 article titled Časopisectvo polské a lužickosrbské [The Polish and Sorbian Magazine Trade]: "It is well known that Cracow's Czas has in recent times been diligently engaged in the Czech question; it remains the only Galician magazine in this regard." 45

Naturally, Jelínek sought out sources and literature not only in domestic institutions. He enjoyed the fact that his work required research in Polish libraries, most of all at the Jagiellonian Library in Cracow. In the early 1880s, Cracow was home to 25 libraries, the most important of which were the Library of the Academy of Learning and the Princes Czartoryski Library, but the Jagiellonian Library, then located on the corner of Jagiellonian Street and St. Anna Street near the main square, stood above the rest. Writing on the importance of Cracow and its famed Jagiellonian Library, Jelínek said that "if Cracow only had hallowed Wawel and the venerable Jagiellonian Library, this would be enough to place it among the most memorable Slavonic cities." ${ }^{46}$ Jelínek admired both the building's exterior (he considered it the most beautiful example of world architecture in Poland in the late $19^{\text {th }}$ century) and the diversity of its interior. Among the library's literary gems (in 1880, it possessed 156,589 volumes) that he had the chance to see, he mentioned the works of Nicolaus Copernicus, Mikołaj Rej of Nagłowice, Jan Długosz, Jan Kochanowski, Adam Mickiewicz, an extensive collection of works by Józef Ignacy Kraszewski, and many other works. As early as in the late 1870s, Jelínek established contact with the library's director, the leading Polish bibliographer Karol Estreicher, whose family hailed from Jihlava (where his ancestor Josef Oestreicher had worked as a brewmaster in the mid- $18^{\text {th }}$ century) and whose grandmother Maria von Ullersberg was from Prague. ${ }^{47}$ These contacts often helped Jelínek gain access to works that were otherwise not easily available. According to Jelínek, the library's second outstanding figure was the historian, librarian, and collector of folk songs Żegota Pauli ${ }^{48}$ who was known in Cracow as a "walking library." 49

Jelínek's personal relationship to the Jagiellonian Library is reflected in the fact that he contributed to the creation of a special Czech section. In a May 1894 letter to the poet and translator František Alois Hora, he wrote: "Despite the unfavorable nature of the times, I am establishing a Czech section at Cracow's Jagiellonian Library. [...]. It is a serious matter, and one of far-ranging importance. This section

45 E. Jelínek, “Časopisectvo polské a lužickosrbské," Osvěta 9, 1879, no. 4, p. 343 [on Polish magazines, see pp. 342-345]. Original: "Že se krakovský Czas v poslední době pilně též zaměstnává otázkou českou, dostatečně jest známo; v tom vzhledě zůstává skoro jediný mezi haličskými časopisy.”

46 E. Jelínek, "V jagiellońské knihovně v Krakově," Slovanský sborník 2, 1883, no. 4, p. 204.

47 E. J. [E. Jelínek], "Karel Estreicher," Světozor 15, 1.7.1881, no. 27, p. 326 [K. Estreicher is shown on p. 317].

48 Cf. E. Jelín ek, “Żegota Pauli,” Český časopis historický 2, 1896, p. 66.

49 E. Jelínek, "V jagiellońské knihovně v Krakově,” p. 208. 
will also include all Czech translations from Polish." ${ }^{50}$ Of the total number of 507 books sent to the library, Jelínek donated 470. In his 1895 will, he bequeathed his Czech books and books on Czech subjects to the Jagiellonian Library; any duplicates went to the Ossolineum in Lvov. Other books and correspondence went to the library of the Museum of the Kingdom of Bohemia. ${ }^{51}$

\section{JELÍNEK'S CONTACTS IN CRACOW AND HIS PUBLICATION INTERESTS}

Starting with his first visits to Cracow, Jelínek began making contacts with various magazine editors and leading figures of Polish cultural and scientific life. From the beginning, his exploration of the city and its culture was aided by the Polish poet and playwright Władysław Anczyc, who among other things was famous for emphasizing the role of the rural population in the country's national life. ${ }^{52}$ In Jelínek's later writings on Cracow, Anczyc was rarely missing. He was a good friend of the Czechs, and so he maintained close and friendly contacts with Jelínek, discussing among other things the living conditions of the Czech peasantry. ${ }^{53}$ Starting in the 1860 s, Anczyc spent the summer months in the mountain resort of Zakopane, and his writings about the Tatra Mountains significantly contributed to the development of the region's tourist industry. Edvard Jelínek's penchant for hiking tours in the Tatras was clearly due to Anczyc's influence.

In the 1880 s, Czech society was represented by various professions in town, and on his visits Jelínek often met local Czechs. One of his warmest memories was of meeting the Czech revivalist poet and promoter of the national cause Boleslav Jablonský (real name Karel Tupý), to whom he was introduced by Anczyc. Jablonský had gained popularity as the regional inspector of suburban schools near Cracow (1858-1867), but he achieved even greater popularity among a broader swath of Polish society as the administrator (and later, prior) of the monastery of the Norbertine Sisters in the village of Zwierzyniec (today part of Cracow) ${ }^{54}$ But the friendship with Jablonský was short-lived, for the prior died in February 1881. Jelínek was later entrusted by the Svatobor association with the task of organizing the official transfer of Jablonský's remains from Cracow ${ }^{55}$ to Prague, and in March he was buried

50 V. Juřina, Edvard Jelinek - osobnost a dilo, p. 99. Original: "Přeze nepřízeň doby zakládám v krakovské Jagellonské knihovně české oddělení. [...]. Věc je vážná a má význam rozsáhlý. Př̀i tomto oddělení budou také všechny české překlady z polštiny."

51 Ibid., pp. 43, 47.

52 E. J. [E. Jelín ek], "Vladislav L. Anczyc," Slovanský sbornik" 2, 1883, no. 9, pp. 475-476.

53 E. Jelín ek, “Boleslav Jablonský v Krakově,” Světozor 22, 21.9.1888, no. 44, p. 691.

54 Ibid., p. 694.

55 The esteem that Jablonský enjoyed among Cracow's residents is evidenced by the number of leading personalities from Cracow and other Polish towns and regions who came to bid him farewell, including the director of the Academy of Learning, Józef Majer; the painter Jan Matejko with students of 
at Vyšehrad Cemetery. ${ }^{56}$ Jelínek was also in close contact with several members of Cracow's Česká Beseda [Czech Forum], who appreciated his work and so decided to purchase all his writings for their library, to which they added over the course of time. In addition, there were both personal and written contacts (including surviving correspondence from 1892-1896) between Jelínek and the Czech businessman (from 1896 chairman of Česká Beseda) Ferdinand Hofman. ${ }^{57}$

Jelínek also nurtured contacts with leading figures of Cracow's cultural and literary life, including the poet, playwright, and politician Adam Asnyk, whom he met as early as 1879 and whom he visited on each of his visits to town. Another friend from Cracow's literary circles was the poet and writer Michał Balucki, who frequently travelled to Bohemia to take in the spas and who organized a celebration in Jelínek's honor in Mariánské Lázně [Marienbad] in $1888 .^{58}$ In addition, there was one more person whose work Jelínek greatly appreciated and with whom he made contact in 1880 while working on the first volume of the Slavonic Symposium. This was the archeologist, publisher, and journalist Adam Honory Kirkor, who had come to Cracow in order to escape persecution in the Russian part of Poland and who had earlier contacts with the Czech scientists and culture workers Karel Vladislav Zap, Ludwik Rittersberg, and Václav Hanka. ${ }^{59}$ Jelínek always enjoyed visiting Kirkor on his visits, and the two often discussed the latest events in Slavic affairs. ${ }^{60} \mathrm{He}$ also attended the famous salons organized by Marie Stojowska, which at the time were the center of cultural life in $\mathrm{Cracow}^{61}$ and where he made many contacts and acquaintances with leading members of Polish cultural and scientific life.

It has already been remarked that Jelínek published his first article in the Polish press in 1873. In the second half of the 1870s, he published an increasing number of texts in Polish periodicals in Poznań, Warsaw, and Lvov, and soon he began working with select magazines and newspapers, usually reporting on Czech cultural life. In Cracow, where he began publishing somewhat later, he collaborated with the daily Czas and the illustrated biweekly Świat. Between 1890 and 1895, he published more than thirty articles in Czas, including the anonymous (he only signed the last one)

the academy; the director of the Jagiellonian Library Karol Estreicher; the painter Juliusz Kossak; writers Adam Asnyk and Władysław Anczyc; the historian Michał Bobrzynski; and many others. See E. Jelín ek, “Boleslav Jablonský v Krakově," Světozor 22, 5. 10. 1888, no. 45, p. 710. See also E. Jelín ek, "Knězbásník” [in:] Slovanské návštěvy. Paměti a vzpominky, Praha 1889, pp. 77-78.

56 For more detail, see E. Jelínek, Vzpomínky na Boleslava Jablonského. Poslední návrat do vlasti, Praha 1881.

57 Cf. V. Juřin a, Edvard Jelínek - osobnost a dilo, p. 67.

58 Cf. ibidem, p. 71.

59 J. [E. Jelín ek], "Slovanský horovatel v Polsce. Vzpomínka na A. H. Kirkora," Slovanský sborník 6,1887 , no. 7 , p. 302 .

60 Ibid., p. 304. On Kirkory, see also E. Jelínek, “Adam Honory Kirkor” [in:] Slovanské návštěvy, pp. $83-116$.

On Jelínek’s contacts with Kirkor, see V. Čejchan, “K počátkům ‘Slovanského sborníku’ Edvarda Jelínka. (Příspěvek na podkladě jeho korespondence s A. H Kirkorem.),” Slovanský přehled 27, 1935, pp. 407-414.

${ }^{61}$ Jelínek's correspondence with Stojowska from the years 1886-1892 has been preserved. 
"Dopisy o české společnosti" [Letters on Czech Society], "Dopisy o české výstavě" [Letters on the Bohemian Exposition], ${ }^{63}$ "Dopisy o moravských věcech" [Letters on Moravian Affairs] ${ }^{64}$ and "Dopis o české národopisné výstavě" [A Letter on the Czech Ethnographic Exposition].$^{65}$ The magazine also published "Listy o wystawie czeskiej" [Letters on the Bohemian Exposition] (Cracow 1891) and "Listy o rzeczach morawskich pisane przes Czecha" [Letters on Moravian Affairs Written by a Bohemian] (Cracow 1894) as standalone publications. ${ }^{66}$ In 1891, Świat magazine published his article "Wystawa jubileuszowa w Pradze czeskiej. (List)" [The Jubilee Exposition in Bohemian Prague. (A Letter) $]^{67}$ and in 1894 it published "Dwa listy Tytusa hr. Działyńskiego do Wacława Hanki" [Two Letters by Tytus Count Działyński to Václav Hanka]. ${ }^{68}$ In printing Działyński’s letters to Hanka, Jelínek was responding to a request by the director of the library in the town of Kórnik, Zygmunt Celichowski, printed in 1878 in Poznań's Lech magazine, where Celichowski had published Hanka's letters to Działyński.

\section{CONCLUSION}

The Czech polonophile Edvard Jelínek was drawn primarily to Warsaw, which in his time was a modern and vibrant city that was growing and developing on all fronts. But $19^{\text {th }}$-century Cracow, though its social and cultural life was not as vibrant, enchanted him by its omnipresent history and tradition. As part of the Austrian monarchy, Jelínek saw Cracow differently than Warsaw, which was controlled by Russia. His writings - which are not academic texts, but heartfelt, often romantically laden, personal reports or sketches - provide an authentic image of Cracow, its atmosphere, and the institutions, landmarks, and people from the worlds of science and culture that he came to know on his visits. His publications are thus a valuable source of information about the city in the 1880 s and 1890 s. Jelínek worked hard to bring together Czechs and Poles through his articles in various newspapers and magazines or in standalone publications. He also organized or co-organized personal encounters in both Bohemia and Poland. For some reason, the academic literature has not paid much attention to the Czech pilgrimage to Cracow in August 1884, organized to a great extent by Jelínek. The main aim of this grand undertaking, which was officially

62 "Listy o towarzystwie czeskim," Czas 43, 1890, no. 290, 291; Czas 44, 1891, no. 6, 7, 12, 13, 14, $16,49,51,57,61,63,67,68,77,97,98,113,114$.

63 "Listy o wystawie czeskiej," Czas 44, 1891, no. 123, 127, 133, 136, 139.

64 "Listy o rzeczach morawskich," Czas 46, 1893, no. 285, 286, 291; Czas 47, 1894, no. 12, 47, 49, 50.

65 “List o etnograficznej wystawie czeskej”, Czas 48, 1895, no. 151.

${ }_{66}$ Also published separately were Jelínek's articles from Dziennik Poznański, see Podatki narodowe w Czechach. Listy do przyjaciela przez Edwarda Jelinka, Poznań 1892.

${ }_{67}$ Świat 4, 1891, pp. 217-218 [a likeness of E. Jelínek can be found on p. 218].

${ }_{68}$ Świat 7, 15.3.1894, pp. 136, 138-139. 
organized by the Sokol club from the town of Kolín, was to reinforce Czech-Polish friendship, and in this regard it was clearly successful. At the same time, however, it was a way for the Czech nation to demonstrate its national consciousness and to introduce its culture to its neighbors.

\section{BIBLIOGRAPHY}

A. Č. [A. Černý], “Z deníku Edvarda Jelínka,” Máj 3, 1905, no. 9, p. 140.

Černý, A., "Edvarda Jelínka život a práce," Slovanský přehled 7, 1905, pp. 97-107.

Černý, A., Vzpominky Edvarda Jelínka, Praha 1904.

Černý, A., "Za Edvardem Jelínkem," Světozor 31, 19.3.1897, no. 19, pp. 225-226; 26.3.1897, no. 20 , pp. $237-238$; 2.4.1897, no. 21 , pp. $247-248,250 ; 9.4 .1897$, no. 22 , pp. 259,$261 ; 16.4 .1897$, no. 23 , pp. 271,$274 ; 23.4 .1897$, no. 24 , pp. $279-282$.

Černý, A., Za Edvardem Jelínkem. Zvláštní otisk ze Světozora čis. 1552-1557, Praha 1897.

“Česká pout' do Krakova," Národni listy 24, 16.8.1884, no. 227, p. 2.

E. J. [E. Jelínek], "Karel Estreicher," Světozor 15, 1.7.1881, no. 27, p. 326.

E. J. [E. Jelínek], "Vladislav L. Anczyc," Slovanský sbornik 2 1883, no. 9, pp. 475-476.

E. J. [E. Jelínek], “Ze života Bedřicha Chopina,” Dalibor 1, 5.12.1873, no. 49, p. 403.

E. J. [E. Jelínek], "Z ujazlovských sadů,” Obrazy života 3, 10.08.1873, no. 21, pp. 330-331.

Hovorka, F. L., "Některé mravy a zvyky polské," Národní listy. Odpoledni vydáni 24, 14.08.1884, no. 225 , pp. $1-2$.

J. [E. Jelínek], "Bratř̆i Poláci a naše Národní divadlo," Divadelní listy 2, 10.09.1881, no. 29, pp. $255-256$.

J. [E. Jelínek], "Slovanský horovatel v Polsce. Vzpomínka na A. H. Kirkora," Slovanský sbornik 6 1887, no. 6, pp. 266-271; 1887, no. 7, pp. 297-305.

Jaroszewicz-Kleindienst, B., $W$ kręgu polonofilskiej działalności Edwarda Jelínka, Wrocław-Warszawa-Kraków 1968.

Jelínek, E., "Biblijografija dzieł, rozpraw i artykułów czeskich dotyczących rzeczy polskich. (Do końca 1877 roku)," Rozprawy i Sprawozdania z Posiedzeń Wydziału Filologicznego Akademii Umiejętności 1880, t. VII, pp. 129-168.

Jelínek, E., "Biblijografija dzieł, rozpraw i artykułów czeskich dotyczących rzeczy polskich. Część druga 1878-1882," Rozprawy i Sprawozdania z Posiedzeń Wydziału Filologicznego Akademii Umiejętności 1884, t. X, pp. 366-384.

Jelínek, E., "Bibliografija przekładów z piśmiennictwa polskiego na język czeski (do końca 1882 roku)," Rozprawy i Sprawozdania z Posiedzeń Wydziału Filologicznego Akademii Umiejętności 1884, t. X, pp. 384-449.

Jelínek, E., "Biblijografija dzieł, rozpraw i artykułów czeskich dotyczących rzeczy polskich. Część trzecia (1883-1886)," Rozprawy i Sprawozdania z Posiedzeń Wydziału Filologicznego Akademii Umiejętności 1889, t. XIII, pp. 159-181.

Jelínek, E., "Bída a milosrdenství v zemích slovanských. II.," Národní listy 19, 16.7.1879, no. 168 , p. 1 .

Jelínek, E., "Bohatství a boháči v zemích slovanských. III.," Národní listy 20, 29.01.1881, no. 24, p. 1.

Jelínek, E., "Boleslav Jablonský v Krakově,” Světozor 22, 21.09.1888, no. 44, pp. 691, 694; 5. 10.1888 , no. 45 , pp. 707,710 .

Jelínek, E., "Časopisectvo polské a lužickosrbské," Osvěta 9, 1879, no. 4, pp. 342-346 [on Polish magazines, see pp. 342-345]. 
Jelínek, E., “Česká pout’ do Krakova 15.-18. srpna 1884,” Slovanský sborník 3, 1884, no. 10, pp. 45-49.

Jelínek, E., "Kościuszkova mohyla," Velký slovanský kalendář na obyčejný rok 188918 , 1888, pp. 101-102.

Jelínek, E., "Kościuszkova mohyla a kopec Unie lubelské," Slovanský sbornik 3, 1884, no. 1 , pp. 45-51.

Jelínek, E., "Krakov,” Národní listy 20, 4.09.1880, no. 213, p. 1.

Jelínek, E., “Obrazy z nynější Polsky. XII. Divadelní rozhled,” Národní listy 20, 24.08.1880, no. 203, pp. 1-2.

Jelínek, E., "Obrazy z nynější Polsky. XIII. Kościuszko v hrobě a na kopci,” Národní listy 20, 16.09.1880, no. 223, p. 1.

Jelínek, E., “'Muzeum techniczno-przemysłowe’v Krakově,” Národní listy 20, 7.09.1880, no. 215 , pp. 1 .

Jelínek, E., Slovanské návštěvy. Paměti a vzpomínky, Praha 1889.

Jelínek, E., "Spis dzieł polskich na język czeski przełożonych," Tygodnik Wielkopolski 3, 22.03.1873, no. 12 , pp. 142-143; 24.08.1873, no. 34, pp. 406-407.

Jelínek, E., "Společnosti a ústavy polské, k nimž jest česká Akademie ve spojení vědeckém. I. Akademie věd v Krakově (Akademia Umiejętności w Krakowie)," Věstník České akademie cisaře Františka Josefa pro vědy, slovesnost a uměni 7, 1894, pp. 369-379.

Jelínek, E., "V jagiellońské knihovně v Krakově," Slovanský sborník 2, 1883, no. 4, pp. 204-208.

Jelínek, E., "Vlastenecká účinnost šlechty polské," Slovanský sborník 4, 1885, no. 4, pp. 186-197.

Jelínek, E., Vzpomínky na Boleslava Jablonského. Poslední návrat do vlasti, Praha 1881.

Jelínek, E., "Żegota Pauli,” Český časopis historický 2, 1896, p. 66.

Juřina, V., Edvard Jelínek - osobnost a dílo, [Praha 1951, dissertation, 155 pp., Jan Palach Library, Faculty of Arts, Charles University].

Kredba, V., “Ze vzpomínek na Edvarda Jelínka,” Slovanský Přehled 27, 1935, p. 405.

"K výletu do Krakova," Př́loha Národních listů 24, 11. 8. 1884, no. 222, p. 3.

"K výletu do Krakova a do Věličky," Národní listy. Odpoledni vydání 24, 13. 6. 1884, no. 163 , p. 2 .

“Na Vysoké Tatry,” Časopis turistů 4, August 1892, no. 8, pp. 203-216.

"Po návratu z Tater," Časopis turistů 4, September 1892, no. 9, pp. 235-236.

"Polské hlasy o nás," Časopis turistů 4, October 1892, no. 10, pp. 271-272; November 1892 , no. 11, pp. 288-290.

"Polské hlasy o nás," Časopis turistů 4, November 1892, no. 11, p. 288.

Pravda, E. [E. Jelínek], "Varšava a její společnost. Dojmy," Slovanský sborník 6, 1887, no. 8, pp. 356-363.

"Výlet do Krakova," Př́loha Národních listů 24, 16.05.1884, no. 136, p. 5.

"Výlet do Tater pořádá Klub českých turistů v měsíci srpnu," Časopis turistů 4, červenec 1892 , no. 7, pp. 169-170. 